\title{
Anti-malarial activity and toxicity assessment of Himatanthus articulatus, a plant used to treat malaria in the Brazilian Amazon
}

\author{
Valdicley V Vale1, Thyago C Vilhena ${ }^{1}$, Rafaela C Santos Trindade², Márlia Regina C Ferreira², Sandro Percário 3,7, \\ Luciana F Soares ${ }^{4}$, Washington Luiz A Pereira ${ }^{5}$, Geraldo C Brandão ${ }^{8}$, Alaíde B Oliveira ${ }^{1,4}$, Maria F Dolabela ${ }^{1,6}$ \\ and Flávio De Vasconcelos ${ }^{1 *}$
}

\begin{abstract}
Background: Plasmodium falciparum has become resistant to some of the available drugs. Several plant species are used for the treatment of malaria, such as Himatanthus articulatus in parts of Brazil. The present paper reports the phyto-chemistry, the anti-plasmodial and anti-malarial activity, as well as the toxicity of $\mathrm{H}$. articulatus.

Methods: Ethanol and dichloromethane extracts were obtained from the powder of stem barks of $H$. articulatus and later fractionated and analysed. The anti-plasmodial activity was assessed against a chloroquine resistant strain P. falciparum (W2) in vitro, whilst in vivo anti-malarial activity against Plasmodium berghei (ANKA strain) was tested in mice, evaluating the role of oxidative stress (total antioxidant capacity - TEAC; lipid peroxidation - TBARS, and nitrites and nitrates - NN). In addition, cytotoxicity was evaluated using the HepG2 A16 cell-line. The acute oral and sub-chronic toxicity of the ethanol extract were evaluated in both male and female mice.

Results: Plumieride was isolated from the ethyl acetate fraction of ethanol extract, Only the dichloromethane extract was active against clone W2. Nevertheless, both extracts reduced parasitaemia in $P$. berghei-infected mice. Besides, a significant reduction in pulmonary and cerebral levels of NN (nitrites and nitrates) was found, as well as in pulmonary TBARS, indicating a reduced oxidative damage to these organs. The ethanol extract showed low cytotoxicity to HepG2 A16 cells in the concentrations used. No significant changes were observed in the in vivo toxicity studies.
\end{abstract}

Conclusions: The ethanol extract of $\mathrm{H}$. articulatus proved to be promising as anti-malarial medicine and showed low toxicity.

Keywords: Himatanthus articulatus, Malaria, Toxicity, Plumieride, Oxidative stress

\section{Background}

The World Malaria Report featured that 207 million cases of malaria occurred worldwide in 2012 with 627.000 deaths [1]. Malaria is found in more than 100 countries, mainly in tropical regions of the world, including Africa, Asia, Central and South America. In Brazil, almost all cases occur in the Legal Amazon [2]. In Brazil, between the years 2000 to 2011 there was a reduction in the

\footnotetext{
*Correspondence: flavio@ufpa.br

'Programa de Pós-graduação em Ciências Farmacêuticas, Instituto de Ciências da Saúde (ICS), Universidade Federal do Pará (UFPA), Rua Augusto Corrêa 1, 68075-110 Belém, PA, Brazil

Full list of author information is available at the end of the article
}

number of malaria cases. In 2011 the number of reported cases was $20 \%$ lower than previous years [3].

The first attempts for a specific treatment of malaria date back to the early 18 th century, with the use of Cinchona tree bark; quinine was isolated as the active ingredient in 1820 [4]. The extensive use of anti-malarial drugs has imposed a tremendous selective pressure on the parasites, leading to the emergence of resistance, particularly in the case of Plasmodium falciparum [5]. Resistance of $P$. falciparum to quinine was reported after 278 years of clinical use, while for the majority of anti-malarial drugs, such as proguanil, sulphadoxine-pyrimethamine and atovaquone, resistance was reported much earlier; in

\section{Ciomed Central}

(c) 2015 Vale et al.; licensee BioMed Central. This is an Open Access article distributed under the terms of the Creative Commons Attribution License (http://creativecommons.org/licenses/by/4.0), which permits unrestricted use, distribution, and reproduction in any medium, provided the original work is properly credited. The Creative Commons Public Domain Dedication waiver (http://creativecommons.org/publicdomain/zero/1.0/) applies to the data made available in this article unless otherwise stated. 
the case of chloroquine and mefloquine, resistance was described after only 10 years of clinical use [6].

New anti-malarial drugs are urgently needed. The candidate drugs ought to be active against both chloroquineand artemisinin-resistant $P$. falciparum strains. It should provide a cure within a reasonable length of time (3 days or less), be safe, at low cost, and should be available in an appropriate formulation for oral use [7].

Investigation of plant-derived compounds is a valid strategy and this approach can take advantage from traditional knowledge of native populations. Indeed, natural products have yielded two of the most important drugs used to treat falciparum malaria so far, quinine and artemisinins [8]. Himatanthus articulatus is in popular use in Brazil for the treatment of several diseases, including skin infections, helminth infestations, gastric diseases, such as peptic ulcers and gastritis [9], tumours [10], syphilis [11], as a cough medicine [12], and as an anti-inflammatory and analgesic [13]. It has been used against malaria [14,15], but this activity does require validation studies.

Popularly known in Brazil as sucuuba, janaguba or sucuba, $H$. articulatus is found in the South America, including Panama, Colombia, Peru, Venezuela, Guyana, Suriname, French Guyana and in the Brazilian Amazon and the Atlantic Forest [12]. The species name $H$. articulatus (Apocynaceae) is synonymous to Himatanthus rigidus, Plumeria articulata Vahl, Plumeria drastica, Plumeria microcalyx and Plumeria sucuuba [16,17]. It is a perennial, heliophytic, selective, xerophytic and secondary plant that inhabits sandy or mixed soils. Its trees can reach 10 to 20 metres in height, present substantial trunks and broken bark, simple and alternate spiral leaves with glabrous coriaceous and entire margins, white flowers of yellow bell-shaped bases, phallic fruits, green colour when immature and dark brown when mature [18].

Several iridoids have already been isolated from this species: plumieride (Figure 1A), isoplumieride (Figure 1B), plumericin (Figure 1C) and isoplumericin (Figure 1D). In addition, also been isolated the triterpenes lupeol cinnamate (Figure 1E), $\alpha$-amyrin cinnamate (Figure $1 \mathrm{~F}), \beta$-amyrin cinnamate (Figure 1G), and lupeol acetate (Figure 1H) [19,20].

Despite the broad popular use of $H$. articulatus bark and latex for the treatment of malaria $[9,10]$, and the promising results described for terpenes [21,22], there is a lack of validation of this activity for this species. A single study has so far evaluated the anti-malarial activity against a chloroquine sensitive clone of $P$. falciparum (3D7), with no activity observed for the ethanol extract obtained from the cortex [10].

The present study describes, for the first time, the anti-plasmodial activity of $H$. articulatus against a chloroquine resistant clone of $P$. falciparum (W2), as well as the anti-malarial activity in Plasmodium berghei-infected mice. Moreover, it describes the results obtained in phytochemical studies and cytotoxicity, acute oral and subchronic toxicity. This study also reports changes in oxidative stress caused in Plasmodium berghei-infected mice.

\section{Methods}

Plant material and phytochemical studies

Stem barks from $H$. articulatus were collected in Altamira city, state of Pará, Brazil (S 01 ${ }^{\circ} 10^{\prime} 86^{\prime \prime}$ W $\left.41^{\circ} 53^{\prime} 51.6^{\prime \prime}\right)$, in

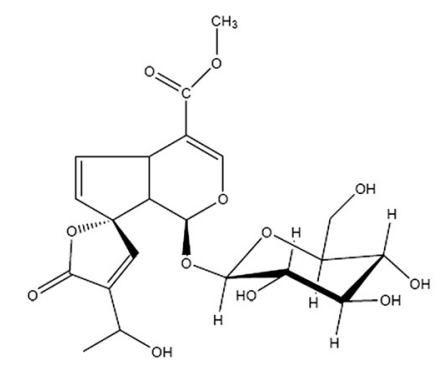

(A)

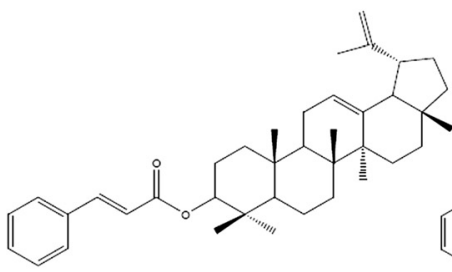

(E)

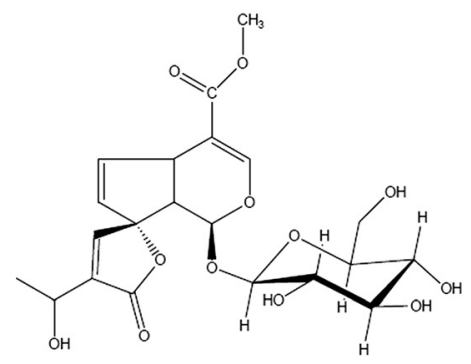

(B)<smiles>C/C=C/C=C/c1ccccc1</smiles>

(F)

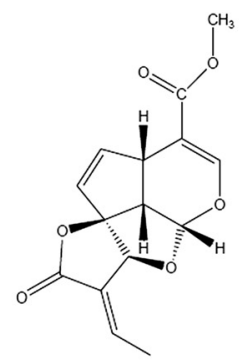

(C)

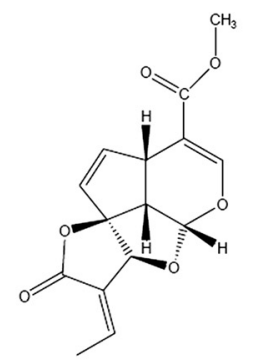

(D)

(D) isoplumericin, (E) lupeol cinnamate, (F) a-amyrin cinnamate, (G) $\beta$-amyrin cinnamate, (H) lupeol acetate. 
the Brazilian Amazon. The dried specimen was deposited in the Museum Paraense Emilio Goeldi (voucher specimen: MG-206619). Subsequently, the barks were washed and dried in an oven with air vent, and triturated in a knife-mill.

The powder $(1.0 \mathrm{~kg})$ was submitted to percolation with ethanol, followed by concentration in a rotary evaporator and lyophilization obtaining ethanol extract (168.2 g). Another part from $H$. articulatus stem bark powder (100 g) was submitted to percolation with hydrochloric acid (1N). The resulting acid solution was alkalized to $\mathrm{pH}$ 9 with ammonium hydroxide, affording the partition with dichloromethane. This solution was concentrated in a rotatory evaporator, obtaining the dichloromethane extract $(0.32 \mathrm{~g})$ [23].

The ethanol extract $(20.00 \mathrm{~g})$ was solubilized with dichloromethane and subjected to a reflux system (20 $\mathrm{min}$ ). Then filtered, and the precipitate was subjected to a procedure similar to ethyl acetate and methanol [24]. The solutions were concentrated in a rotary evaporator, and it was obtained dichloromethane (2.615 g), ethyl acetate $(5.38 \mathrm{~g})$ and methanol $(9.98 \mathrm{~g})$ fractions. The ethyl acetate fraction $(3.50 \mathrm{~g})$ was fractionated by silica gel column $(60.0 \times 2.5 \mathrm{~cm})$ and eluted with solvents and mixture of these at increasing polarities (hexane, dichloromethane, ethyl acetate and methanol). Fraction $6(3.2 \mathrm{~g})$ was later fractionated in chromatographic column with silica gel $(80 \times 2 \mathrm{~cm})$ with solvents at increasing polarities. Sub-fraction 6-8 (1.01 g of plumieride) underwent spectroscopic analyses (NMR, LC-UV-MS).

The ethanol extract, fractions and plumieride underwent evaluation by high performance liquid chromatography with diode array detector (HPLC-DAD, Waters mod. 2695, USA), C-18 reverse phase column $(5 \mu \mathrm{m}, 125 \times 45 \mathrm{~mm}$, LiChrocart 125-4, Merck, Germany), at $40^{\circ} \mathrm{C}$, flow rate of $1 \mathrm{~mL} / \mathrm{min}$, wavelengths scanning from 220 to $400 \mathrm{~nm}$. As mobile phase, a linear gradient of 5\% (acetonitrile) and 95\% (aqueous solution of phosphoric acid $0.1 \% \mathrm{v} / \mathrm{v}$ ) at time 0 and $65 \mathrm{~min}$ with 95\% (acetonitrile) and 5\% (aqueous solution of phosphoric acid $0.1 \% \mathrm{v} / \mathrm{v}$ ) were used. For the dichloromethane fraction, the initial gradient was acetonitrile $90 \%$ and aqueous solution $10 \%$ of phosphoric acid $0.1 \% \mathrm{v} / \mathrm{v}, 10$ to 30 minutes, followed by $80 \%$ of acetonitrile and $20 \%$ aqueous solution of phosphoric acid $0.1 \%$ $\mathrm{v} / \mathrm{v}$ from 30 to 32 minutes. Finally, $50 \%$ of acetonitrile and $50 \%$ aqueous solution of phosphoric acid $0.1 \% \mathrm{v} / \mathrm{v}$ were used henceforth.

The following spectroscopy methods were used for structural identification: Ultra High Performance Liquid Chromatography coupled to UV and Mass Spectrometry by Electron Spray Ionization (UPLC-PDA-MS/ESI Acquity $\mathrm{H}$-Class Core System ${ }^{\circ}$ Waters, USA), ${ }^{1} \mathrm{H}$ NMR, ${ }^{13} \mathrm{C}$ NMR and DEPT 135 (Bruker NMR spectrometer Advance DPX
200, Bruker, USA). The positive mode was used to obtain electron spray ionization mass spectrometry (Acquity $\mathrm{H}$-Class Core System ${ }^{\circ}$ Waters, USA), with capillary voltage of $3.5 \mathrm{eV}$, the cone $60 \mathrm{eV}$, CSH130 C-18 column (particles of $1.7 \mu \mathrm{m}, 50 \times 3 \mathrm{~mm}$ ), flow of $0.3 \mathrm{~mL} / \mathrm{min}$, temperature of $40^{\circ} \mathrm{C}$ and UV detection between 220 and $400 \mathrm{~nm}$. As mobile phase, a linear gradient was used, in which the initial time contained aqueous solution of formic acid $0.1 \%$ (A) and acetonitrile with formic acid $0.1 \%$ (B), in $10 \mathrm{~min} 5 \%$ of $\mathrm{A}$ and $95 \% \mathrm{~B}$. The NMR used deuterated methanol (Merck, Germany).

\section{Cytotoxicity assay}

The cell viability was determined by the MTT (3- (4,5dimethyltrazol-2-yl)-2,5-diphenyl tetrazolium bromide) method according to Mosman [25]. HepG2 A16 cells $\left(4 \times 10^{5}\right.$ cells $/ 0.1 \mathrm{~mL}$ ) were grown in RPMI-1640 (Roswell Park Memorial Institute 1640) medium (Sigma Aldrich ${ }^{\circ}$, USA), supplemented with $5 \%$ of foetal calf serum, kept in a $5 \% \mathrm{CO}_{2}$ atmosphere at $37^{\circ} \mathrm{C}$. The ethanol extract from $H$. articulatus was solubilized in RPMI-1640 and dimethyl sulphoxide $(0.02 \%, \mathrm{v} / \mathrm{v})$. After $24 \mathrm{~h}$, the solution was added at different concentrations (in $\mu \mathrm{g} / \mathrm{mL}: 1,10,100,1000$ ), followed by 24 hours of further incubation. The MTT (2.0 $\mathrm{mg} / \mathrm{mL}$ ) was added, followed by incubation at $37^{\circ} \mathrm{C}$ in an atmosphere of $5 \% \mathrm{CO}_{2}$ for 4 hours. Dimethyl sulphoxide was added to each well, and the reactions were mixed to solubilize the formazan crystals. The optical density was determined at $570 \mathrm{~nm}$ and $630 \mathrm{~nm}$ to measure the signal and background, respectively (Stat Fax 2100 microplate reader, Awareness Technology, Inc., USA). The cell viability was expressed as a percentage of the control absorbance in the untreated cells after subtracting the appropriate background and the average cytotoxic concentration $\left(\mathrm{CC}_{50}\right)$ was determined by linear regression.

\section{Evaluation of anti-plasmodial activity in vitro}

Plasmodium falciparum (strain W2) was grown according to Trager and Jensen [26], synchronized with 5\% sorbitol [27]. Evaluation of in vitro anti-malarial activity was performed by the quantification of parasitic enzyme lactate dehydrogenase $(p \mathrm{LDH}),[28,29]$. The test used the trophozoite stage (parasitaemia of $2 \%$ and haematocrit of $1 \%$ ) and different concentrations of test samples (in $\mu \mathrm{g} / \mathrm{mL}$ : $50.00,25.00,12.50,6.25$ and 1.56). Normal not infected red blood cells (RBCs) were used as negative control and as positive control, parasitized- and non-treated RBCs. Chloroquine was used as a standard anti-malarial drug. After $48 \mathrm{~h}$ of incubation under $\mathrm{CO}_{2}$, plates were frozen (twice) to promote cell lysis. Fifteen $\mu \mathrm{L}$ of lysate was added to Malstat reagent $(100 \mu \mathrm{L})$ and NBT/FT $(25 \mu \mathrm{L})$, followed by incubation $\left(1 \mathrm{~h}\right.$ at $\left.37^{\circ} \mathrm{C}\right)$ under light and subsequent reading at $540 \mathrm{~nm}$. Cell viability (\%) was calculated as the 
Table 1 Yield and anti-plasmodial activity of samples

\begin{tabular}{lll}
\hline Samples & Yield (\%) & Anti-plasmodial activity $\mathbf{I C}_{\mathbf{5 0}} \pm \mathbf{S D}(\boldsymbol{\mu \mathbf { g } / \mathbf { m L } )}$ \\
\hline EEHa & 16.8 & $>50.00$ \\
FrDCM & 13.1 & $>50.00$ \\
FrAcOET & 26.9 & $>50.00$ \\
FrMeOH & 49.9 & $>50.00$ \\
DCME Ha & 0.2 & $22.90 \pm 0.20$ \\
PLUMIERIDE & 24.3 & $>50.00$ \\
Cloroquine & - & $0.15 \pm 0.06$
\end{tabular}

EEHa-ethanol extract from Himatanthus articulatus stem bark; FrDCMdichloromethane fraction obtained from ethanol extract of Himatanthus articulatus bark; FrAcOET- ethylacetate fraction obtained from ethanol extract of Himatanthus articulatus bark; FrMeOH-methanol fraction obtained from ethanol extract of Himatanthus articulatus bark; DCME Ha - dichloromethane extract obtained from Himatanthus articulatus bark powder; PLUMIERIDE-iridoid compound isolated from FrAcOET; Cloroquine-positive control.

ratio between non-infected (100\% viables) and infected ( $0 \%$ viables) $\mathrm{RBCs}$. The $\mathrm{IC}_{50}$ was determined by means of linear regression curve.

\section{Evaluation of acute oral and subchronic toxicity}

Male $(n=8)$ and female $(n=8$, nulliparous and nonpregnant) albino Swiss mice, weighing 25-27g, obtained from the animal facility of the Instituto Evandro Chagas, (IEC), Ananindeua, Pará, Brazil, were kept in the vivarium of the Faculty of Pharmacy (UFPA) under controlled temperature and humidity, light and dark cycle of $12 \mathrm{~h}$ each, with pelleted food and filtered tap water ad libitum. They were daily submitted, weighed, and assessed for food and water intake. At the end of the experiment, animals were anesthetized and euthanized, samples of blood were drawn and target organs were removed for anatomo- and histopathological evaluation (liver, kidneys, pancreas, brain and heart) [30,31]. The following laboratory tests (in sub-chronic test) were performed: complete blood count, liver function tests, total proteins, albumin, uric acid, urea, cholesterol, triglycerides [31] and hepatic lipid peroxidation (TBARS method).

For the acute oral toxicity test, it was used the Fixed Procedure Test, according to the guideline from OECD [30], with minor modifications. The animals were submitted to treatment by a single dose $(5,000 \mathrm{mg} / \mathrm{kg}$; gavage) and were evaluated by the Hippocratic test during 14 days. For the sub-chronic toxicity test, animals were treated with extract (200 mg/kg and $100 \mathrm{mg} / \mathrm{kg}$ each group) for 38 days and a satellite group was maintained for a further 14 days without treatment [31]. All procedures were in accordance to the ethical principles of Animal Experimentation, and the study was approved by the Ethics Committee (CEPAN /IEC/SVS/MS) under report number 045/2009.

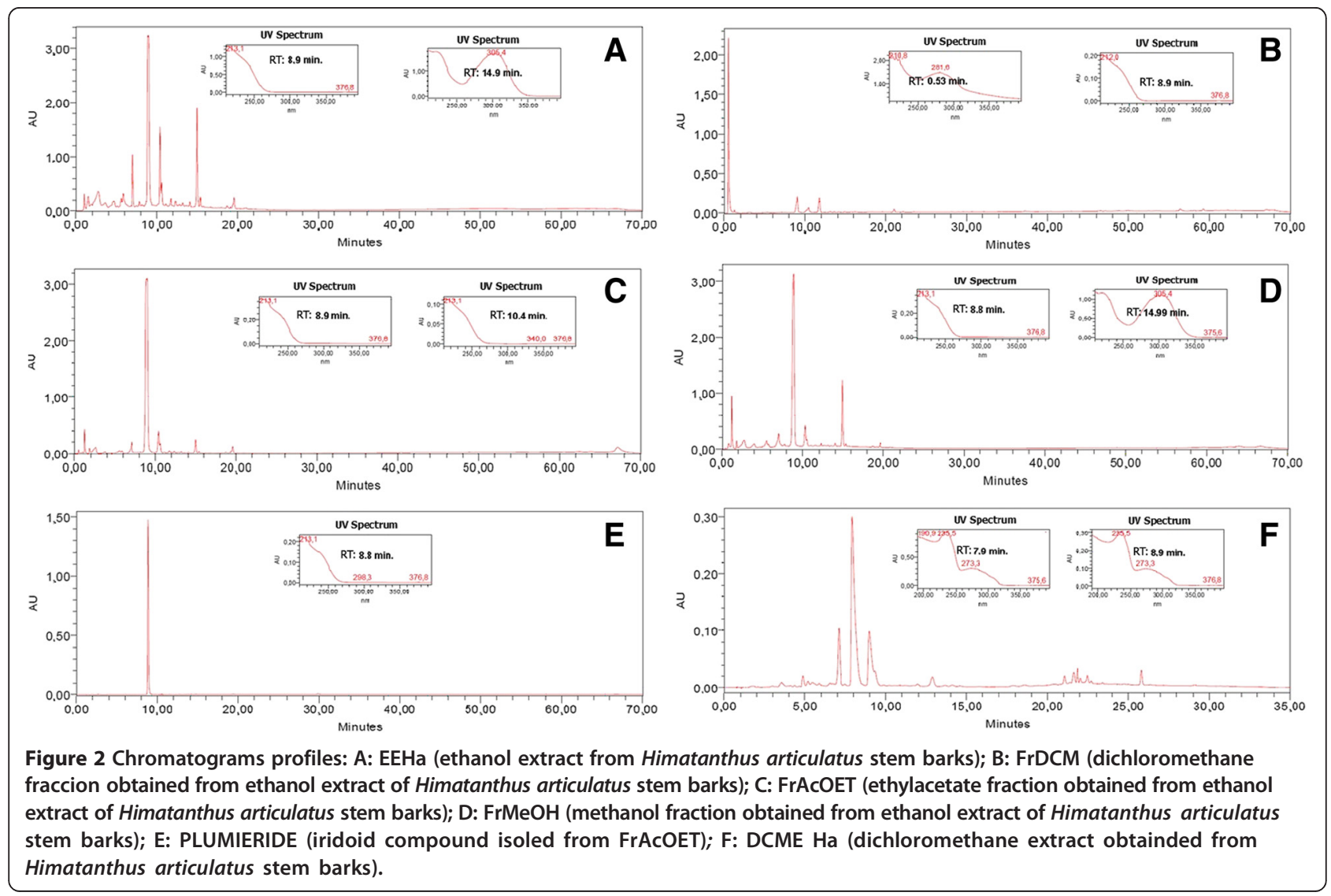




\section{Experimental in vivo malaria}

The anti-malarial activity was performed as established by Peters [32], with modifications. Swiss albino male mice $(n=10)$ were 10 days orally pre-treated with the ethanol extract $(200 \mathrm{mg} / \mathrm{kg})$, followed by subsequent infection with $P$. berghei. New treatment $(200 \mathrm{mg} / \mathrm{kg})$ was performed for 5 days. On the $5^{\text {th }}$ day after the infection, blood samples were drawn, animals were anesthetized for euthanasia and brain and lungs were removed for evaluation of TEAC (Trolox ${ }^{\circledR}$ Equivalent Antioxidant Capacity), NN (Nitrite and Nitrate) and TBARS (Thiobarbituric Acid Reactive Substances). Animals $(n=10)$ treated with filtered tap water under the same conditions as their counterparts in the treated group were used as a negative control.

Determination of the TEAC was performed according to Miller et al. [33]. Lipid peroxidation was assessed by the measurement of the TBARS, according to Percário et al. [34]. The levels of NN were assayed by the Griess method [35], using the nitrate/nitrite colourimetric assay kit (Cayman Chemical Co., USA)

\section{Statistical analysis}

For cytotoxicity and anti-plasmodial assay it was used linear regression. For acute oral toxicity, oxidative parameters and antioxidant defenses it was applied the Student $t$-test for non-paired data, with a significance level set at $p<0.05$. For sub-chronic toxicity it was used analysis of variance (ANOVA), followed by Tukey's post hoc test $(p<0.05)$.

\section{Results and discussion}

\section{Phytochemical analysis}

The lyophilized ethanol extract from $H$. articulatus stem barks was fractionated by re-extraction under reflux yielding three fractions: the dichloromethane, the ethyl acetate and the methanol fractions (Table 1). The ethyl acetate fraction presented an HPLC-DAD profile (Figure 2C) suggestive of iridoids and, therefore, it was submitted to further fractionation affording sub-fraction 6-8 which was spectroscopically (UV, ${ }^{1} \mathrm{H} \mathrm{NMR},{ }^{13} \mathrm{C} \mathrm{NMR}$, DEPT 135 and MS) characterized as plumieride (Table 2 and Figure 3), the major iridoid found in this plant species $[19,20,36]$.

HPLC-DAD analysis of ethanol extract and fractions (Figure 2) showed the presence of peaks of compounds with high polarity. In all samples, except for the alkaloid fraction (Figure 2F), there is a predominant peak (retention time $=8.9$ minutes) and an UV spectrum suggestive of iridoid chromophore [37]. This hypothesis was strengthened by injection of plumieride whose retention time and UV spectra were identical (Figures 2A, C, D and E). Due to low yield of fractions and plumieride, in vivo studies were not possible to be performed.
Table $2{ }^{1} \mathrm{H}$ and ${ }^{13} \mathrm{C}$ data for plumieride

\begin{tabular}{|c|c|c|c|c|}
\hline \multirow[t]{2}{*}{ Position } & \multicolumn{2}{|c|}{$\delta_{\mathrm{H}} \mathrm{ppm}(200 \mathrm{MHz})$} & \multicolumn{2}{|c|}{$\delta_{\mathrm{C}} \mathrm{ppm}(200 \mathrm{MHz})$} \\
\hline & Presentwork & $\begin{array}{l}\text { BARRETO et al., } \\
2007\end{array}$ & $\begin{array}{l}\text { Present } \\
\text { work }\end{array}$ & $\begin{array}{l}\text { BARRETO et al., } \\
2007\end{array}$ \\
\hline 1 & $5.3(d)$ & $5.5(d)$ & 94.2 & 93.5 \\
\hline 3 & $7.5(\mathrm{~s})$ & $7.6(s)$ & 152.6 & 152.7 \\
\hline 4 & - & - & 111.1 & 111.1 \\
\hline 5 & - & - & 40.4 & 38.8 \\
\hline 6 & $6.4(\mathrm{dd})$ & $6.7(\mathrm{dd})$ & 141.5 & 143.3 \\
\hline 7 & $5.5(\mathrm{dd})$ & $5.7(\mathrm{dd})$ & 130.0 & 129.1 \\
\hline 8 & - & - & 97.9 & 97.6 \\
\hline 9 & $3.2(d d)$ & $3.2(d d)$ & 50.6 & 46.4 \\
\hline 10 & $7.4(s)$ & $7.6(s)$ & 150.3 & 152.7 \\
\hline 11 & - & - & 138.6 & 139.3 \\
\hline 12 & - & - & 172.8 & 174.6 \\
\hline 13 & - & - & 63.6 & 63.6 \\
\hline 14 & $1.4(\mathrm{~d})$ & $1.6(d)$ & 22.5 & 22.4 \\
\hline 15 & - & - & 168.5 & 170.4 \\
\hline 16 & $3.7(\mathrm{~s})$ & $3.9(\mathrm{~s})$ & 52.1 & 53.6 \\
\hline $1^{\prime}$ & $4.7(d)$ & $4.9(\mathrm{~d})$ & 100.1 & 99.8 \\
\hline $2^{\prime}$ & $2.9(\mathrm{~m})$ & $3.9(\mathrm{~m})$ & 74.7 & 74.3 \\
\hline $3^{\prime}$ & $3.5(\mathrm{~m})$ & $3.4(\mathrm{~m})$ & 77.8 & 77.3 \\
\hline $4^{\prime}$ & $4.5(\mathrm{dd})$ & $4.0(\mathrm{~m})$ & 71.3 & 71.2 \\
\hline $5^{\prime}$ & 3.8 (m) & $3.6(\mathrm{~m})$ & 78.9 & 78.0 \\
\hline $6^{\prime}$ & $3.4(\mathrm{~m})$ & $4.0(\mathrm{~m})$ & 62.6 & 62.4 \\
\hline
\end{tabular}

d-doublet, dd-double doublet, s-singlet, m-multiplet.

Himatanthus articulatus belongs to the Apocynaceae family, which is known to produce alkaloids [38]. However, previous studies have not yet described the isolation of alkaloids in this species [20,39]. Possibly, this class of natural products is a minor constituent in $H$. articulatus, if present at all. To address this question, a selective extraction for alkaloids was performed. The resulting dichloromethane extract showed three major peaks in the HPLC-DAD (Figure 2F). The UV spectrum of the most intense one showed $\lambda_{\max }=235$ and $273 \mathrm{~nm}$. Due to the low yield $(0.16 \%)$ of this extract no compound could be isolated. However, analyses by UPLC-UV-MS/ESI have shown that as the major constituent, showing a peak at $\mathrm{RT}=7.91 \mathrm{~min}(52.83 \%$ area; Figure $2 \mathrm{~F})$ and a pseudo molecular ion $[M+1]=329 \mathrm{u}$. Moreover, due to the low quantity of dichloromethane extract available, in vivo studies were not performed.

The chromatography study showed chemical similarity between the ethanol extract and its fractions (Figure 2). Currently, animal testing should be conducted in compliance with the principle of the 3Rs (reduction, refinement and replacement) [40]. As the ethanol extract has chemical similarities with all its fractions, it was 


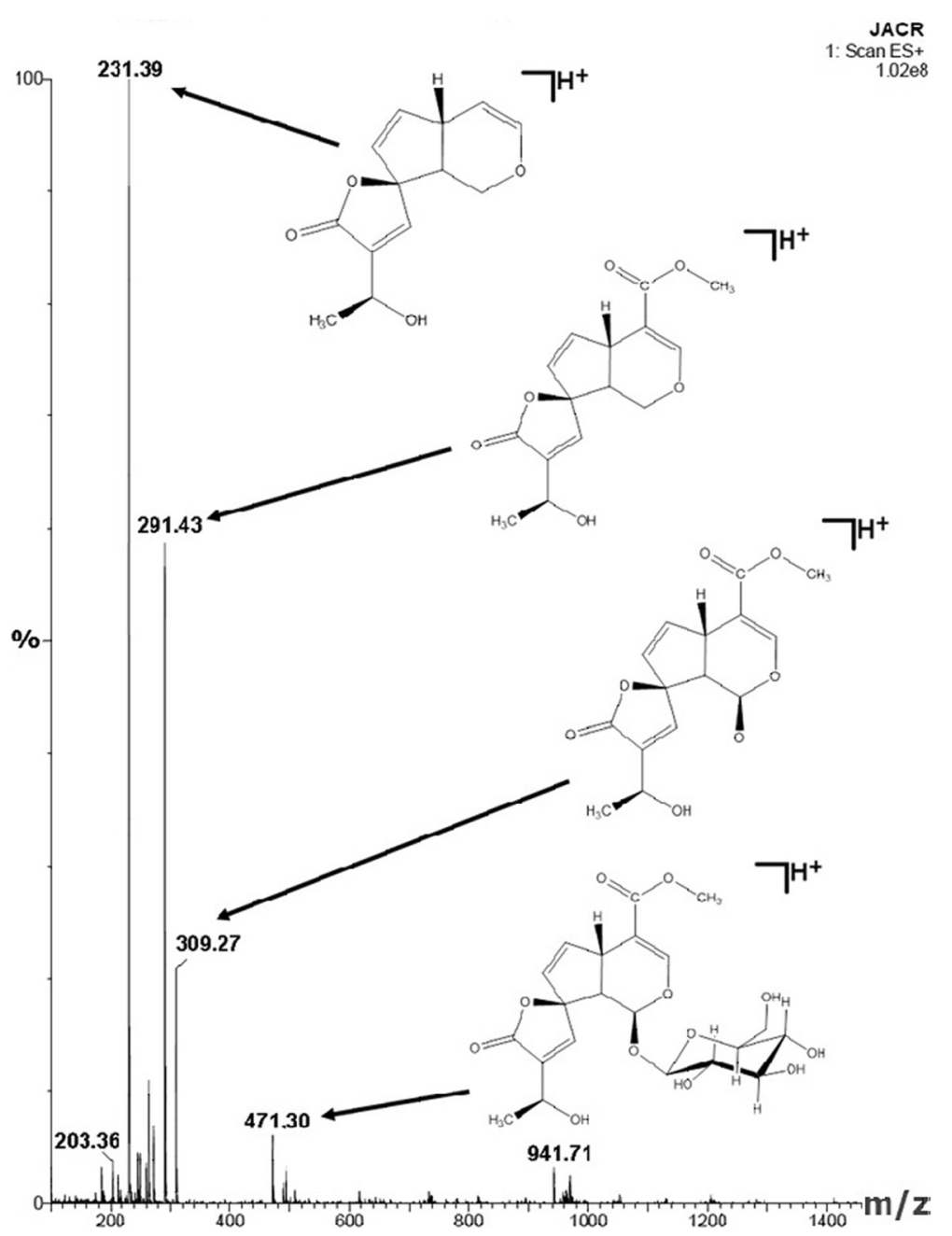

Figure 3 Mass spectrum of plumieride registered online by UPLC-UV-MS/ESI showing pseudomelecular ion and fragments derived from it.

decided to carry out in vivo studies with the ethanol extract only. Thus, there was a significant reduction of the number of animals used.

\section{Anti-malarial activity}

All samples were submitted to anti-plasmodial activity evaluation by the pLDH method [28,29]. The ethanol extract, its fractions and plumieride were inactive against the chloroquine-resistant $P$. falciparum W2 clone (Table 1). Another iridoid (8-THE-acetylharpagide) also proved to be inactive against chloroquine-sensitive $P$. falciparum [41]. Collectively, these results suggest iridoidrich extracts are inactive. Nevertheless, in vivo studies are still needed and deserve to be investigated. By contrast, the dichloromethane extract proved to be active against this clone $\left(\mathrm{IC}_{50}=22.9 \pm 0.2 \mu \mathrm{g} / \mathrm{mL}\right.$; Table 1$)$.

The barks of $H$. articulatus are widely used for malaria treatment in the Amazon traditional medicine [9], suggesting the hypothesis that this species might interfere in the pathogenesis of the disease. Therefore, the ethanol extract was subjected to in vivo studies against $P$. bergheiinfected mice when parasitaemia and oxidative parameters were evaluated (TBARS, TEAC and NN).

Further, contrarily to the in vitro study, the ethanol extract significantly reduced parasitaemia by $35.4 \%$ at a dose of $200 \mathrm{mg} / \mathrm{kg}$. Plant extracts in which the reduction of parasitaemia is greater than $30 \%$ are considered active [42]. Several factors may be influencing this divergence of results amongst them: differences between the parasites used in the studies, or perhaps the extract contains a substance that requires prior hepatic metabolism to become active [43].

In addition, the mechanisms that trigger the respiratory distress present in pulmonary malaria are multifactorial. There is an evidence of the involvement of free radicals affecting cell membranes, attacking the endothelium and changing the vascular permeability [44]. An important mediator of this process seems to be nitric oxide [45]. 
Table 3 Oxidative stress parameters of mice from both groups

\begin{tabular}{|c|c|c|c|c|c|c|}
\hline \multirow[t]{2}{*}{ Groups } & \multicolumn{2}{|l|}{$\mathrm{NN}(\mu \mathrm{M})$} & \multicolumn{2}{|l|}{ TBARS ( $\mu \mathrm{g} / \mathrm{L})$} & \multicolumn{2}{|c|}{ TEAC (mM/L) } \\
\hline & Brain & Lung & Brain & Lung & Brain & Lung \\
\hline Infected & $507.3 \pm 52.2$ & $408.8 \pm 49.1$ & $224.8 \pm 66.2$ & $86.9 \pm 40.5$ & $20.0 \pm 3.4$ & $11.0 \pm 3.3$ \\
\hline EEHa & $315.8 \pm 57.0^{*}$ & $257.8 \pm 48.0^{*}$ & $258.2 \pm 57.7^{\mathrm{NS}}$ & $38.0 \pm 16.2^{*}$ & $21.5 \pm 5.2^{\mathrm{NS}}$ & $6.1 \pm 9.6^{\mathrm{NS}}$ \\
\hline
\end{tabular}

Values are presented as mean \pm standard deviation ( $\mathrm{n}=10$ animals). Infected Group: Plasmodium berghei-infected mice; EEHa: Plasmodium berghei-infected mice and treated with EEHa (ethanol extract from Himatanthus articulatus stem bark) $200 \mathrm{mg} / \mathrm{Kg}$, orally. NN: nitrite/nitrate; TBARS: thiobarbituric acid reactive substances; TEAC: Trolox ${ }^{\circledR}$ Equivalent Antioxidant Capacity. ${ }^{*} p<0.05$ versus Infected Group. NS Non-significant versus Infected Group. Student's. "t" Test.

Furthermore, Pino et al. [46] observed that the adhesion of parasitized erythrocytes to human pulmonary endothelium may be regulated by TNF, cytokine that induces the expression of iNOS enzymes, suggesting that the inhibition of NO synthesis may indeed protect pulmonary endothelial cells. Additionally, Dimmeler et al. [47] observed that iNOS inhibition by N-monomethyl-L-arginine (L-NMMA) impairs TNF induced endothelial cells apoptosis and, therefore, might be a protective mechanism.

In the present study, a significant decrease in the levels of brain and pulmonary nitrite and nitrate was observed (Table 3). These data suggest that the ethanol extract of $H$. articulates plays an inhibitor role upon NO synthesis and/or decreases $\mathrm{NO}$ concentration by directly scavenging it, thus potentially protecting the respiratory epithelium and reducing the severity of the respiratory distress to the animals.

In parallel, the TBARS assesses the intensity of lipid peroxidation, which contributes to the inflammatory reaction due to the activation of pro-inflammatory cytokines, such as lymphotoxin and TNF) and IL-8. The reduction in TBARS levels found in the lungs of infected-and treated-animals (Table 3) may indicate a reduction of pulmonary inflammation and, possibly, an additional effect of $\mathrm{NO}$ decreased synthesis or of antioxidants present in the extract. In fact, in spite of no differences in TEAC values were seen between groups, it is possible to state that the ethanol extract may have some antioxidant properties, as several iridoids are regarded as antioxidant molecules $[48,49]$.

In relation to brain findings, despite the reduction of nitrite and nitrate levels, no differences for TBARS and TEAC were found between groups. These results may indicate that the blood brain barrier could prevent the passage of certain constituents of the extract. Another possibility lies on the high cholesterol content of neuronal cells, as they are suitable to intense lipid peroxidation, whose might have surpassed the potential antioxidant effects of the extract.

In summary, the ethanol extract of $H$. articulatus reduced parasitaemia in $P$. berghei-infected mice. This extract also significantly interfered in oxidative parameters related to the pathogenesis of malaria. These results leads us to the following thought: when a plant species, of broad popular use for malaria, produces negative results in in vitro assays, in vivo studies ought to be performed. Such in vivo experiments should ascertain both clinical and parasitological aspects of the disease. Only then is it possible to validate anti-malarial activity of a certain natural product.

\section{Toxicity studies}

Due to significant anti-malarial activity of the ethanol extract, cytotoxicity, acute in vivo and sub-chronic toxicity evaluations were performed. The ethanol extract

Table 4 Hematological values of 38 days EEHa-treated mice

\begin{tabular}{|c|c|c|c|c|c|c|c|c|}
\hline \multirow{2}{*}{$\begin{array}{l}\text { Hematological } \\
\text { parameters }\end{array}$} & \multicolumn{4}{|l|}{ Males $(n=8)$} & \multicolumn{4}{|c|}{ Females $(n=8)$} \\
\hline & $C$ & T200 & T100 & $\mathrm{S}$ & $C$ & $\mathrm{~T} 200$ & T100 & $\mathrm{S}$ \\
\hline WBC $\left(10^{3} / \mathrm{mm}^{3}\right)$ & $6.0 \pm 1.6$ & $10.0 \pm 2.8$ & $10.0 \pm 1.6$ & $7.9 \pm 3.0$ & $4.6 \pm 0.4$ & $5.4 \pm 1.5$ & $6.3 \pm 1.4$ & $14.5 \pm 2.1^{*}$ \\
\hline $\mathrm{RCB}\left(10^{6} / \mathrm{mm}^{3}\right)$ & $6.5 \pm 2.3$ & $7.4 \pm 0.7$ & $7.8 \pm 0.5$ & $7.8 \pm 0.7$ & $5.0 \pm 0.6$ & $5.1 \pm 0.8$ & $7.6 \pm 0.3^{*}$ & $7.9 \pm 0.5^{*}$ \\
\hline $\mathrm{Hb}(\mathrm{g} / \mathrm{dL})$ & $12.1 \pm 3.9$ & $11.8 \pm 1.3$ & $12.9 \pm 0.6$ & $12.9 \pm 1.4$ & $7.8 \pm 1.1$ & $8.3 \pm 0.9$ & $13.0 \pm 0.7^{*}$ & $13.3 \pm 0.9^{*}$ \\
\hline Hem (\%) & $35.8 \pm 1.1$ & $35.1 \pm 2.6$ & $39.2 \pm 0.9$ & $39.6 \pm 4.0$ & $24.0 \pm 2.5$ & $25.2 \pm 3.2$ & $39.3 \pm 1.5^{*}$ & $40.8 \pm 2.5^{*}$ \\
\hline MCV (fL) & $48.6 \pm 1.6$ & $49.1 \pm 0.7$ & $49.4 \pm 0.9$ & $50.5 \pm 0.6$ & $48.3 \pm 0.7$ & $48.8 \pm 1.4$ & $52.0 \pm 0.5^{*}$ & $51.5 \pm 0.6^{*}$ \\
\hline $\mathrm{MCH}(p g)$ & $16.5 \pm 1.1$ & $16.0 \pm 0.6$ & $16.4 \pm 0.7$ & $16.3 \pm 0.4$ & $15.8 \pm 0.7$ & $15.9 \pm 0.6$ & $16.9 \pm 0.7$ & $16.8 \pm 0.3$ \\
\hline HCMC (g/dL) & $33.6 \pm 1.1$ & $32.4 \pm 0.6$ & $32.9 \pm 0.5$ & $32.4 \pm 0.4$ & $31.8 \pm 0.5$ & $32.7 \pm 0.5$ & $32.9 \pm 0.7^{*}$ & $32.6 \pm 0.5$ \\
\hline Plat $\left(10^{3} / \mathrm{mm}^{3}\right)$ & $244.5 \pm 63.0$ & $445.3 \pm 74^{*}$ & $403.0 \pm 53.7$ & $400.0 \pm 145.1$ & $283.3 \pm 7.8$ & $207.0 \pm 43.4$ & $346.0 \pm 49.5$ & $403.3 \pm 161$ \\
\hline
\end{tabular}

EEHa: Ethanol extract from Himatanthus articulatus stem bark; WBC- white blood cell count; RCB- red blood cell count; Hb- hemoglobin; Hem- hematocrit; MCV- mean corpuscular volume; HCM- mean corpuscular hemoglobin; $\mathrm{CHCM}$ - mean corpuscular hemoglobin concentration; Plat- platelets; $\mathrm{C}$ - control group; T200- group treated orally with EEHa $(200 \mathrm{mg} / \mathrm{Kg}) ; \mathrm{T} 100$ - group treated orally with EEHa (100 mg/Kg); S- satellite group. * $p<0.05$ versus control group. 
Table 5 Laboratory patterns of 38 days EEHa-treated mice

\begin{tabular}{|c|c|c|c|c|c|c|c|c|}
\hline \multirow{2}{*}{$\begin{array}{l}\text { Laboratory } \\
\text { Parameters }\end{array}$} & \multicolumn{4}{|c|}{ Males $(n=8)$} & \multicolumn{4}{|c|}{ Females $(n=8)$} \\
\hline & $\mathrm{C}$ & T200 & T100 & $S$ & C & T200 & T100 & $\mathrm{S}$ \\
\hline AST (UI/L) & $136.7 \pm 52.3$ & $111.0 \pm 56.6$ & $147.0 \pm 59.6$ & $82.2 \pm 17$ & $83.5 \pm 6.4$ & $124.0 \pm 18.4$ * & $65.0 \pm 32.4$ & $88.3 \pm 19.5$ \\
\hline ALT (UI/L) & $7.7 \pm 2.9$ & $8.2 \pm 1.7$ & $7.5 \pm 1.3$ & $8.2 \pm 2.1$ & $16.0 \pm 1.4$ & $7.0 \pm 1.4^{*}$ & $6.0 \pm 0.0 *$ & $6.4 \pm 0.9^{*}$ \\
\hline$\gamma$ GT (UI/L) & $11.5 \pm 10.6$ & $4.0 \pm 0.0$ & $4.2 \pm 0.4$ & $4.0 \pm 0.0$ & $4.0 \pm 0$ & $4.3 \pm 0.6$ & $4.0 \pm 0.0$ & $4.0 \pm 0.0$ \\
\hline Alb (g/dL) & $2.9 \pm 0.4$ & $2.3 \pm 0.2 *$ & $2.6 \pm 0.1$ & $2.4 \pm 0.2$ & $3.4 \pm 0.9$ & $2.4 \pm 0.5$ & $2.4 \pm 0.4$ & $2.4 \pm 0.2$ \\
\hline $\mathrm{TP}(\mathrm{g} / \mathrm{dL})$ & $6.4 \pm 2,35$ & $4.2 \pm 0.2^{*}$ & $4.3 \pm 0.1$ & $4.5 \pm 0.4$ & $4.7 \pm 0.6$ & $3.6 \pm 0.7$ & $3.9 \pm 0.3$ & $4.7 \pm 0.3$ \\
\hline TC (mg/mL) & $95.0 \pm 15.4$ & $83.7 \pm 3.2$ & $86.0 \pm 4.2$ & $86.7 \pm 4.3^{*}$ & $99.3 \pm 10.0$ & $66.6 \pm 7.6^{*}$ & $83.5 \pm 5.8$ & $67.3 \pm 3.2^{*}$ \\
\hline TGD (mg/mL) & $163.0 \pm 31.1$ & $205.7 \pm 15.0^{*}$ & $185.3 \pm 12.7$ & $229.7 \pm 2.5^{*}$ & $173.3 \pm 17.8$ & $132.5 \pm 17.7$ & $154.0 \pm 12.1$ & $163.8 \pm 18,5$ \\
\hline
\end{tabular}

EEHa: Ethanol extract from Himatanthus articulatus stem bark; AST-aspartate aminotransferase; ALT-alanine aminotransferase; $\gamma \mathrm{GT}$ - gamma glutamyl transferase; Alb- albumin; TP- total protein; TC- Total cholesterol; TGD- triglycerides; Ur- urea; UA- uric acid; C- control group; T200- group treated orally with EEHa (200 mg/Kg); T100- group treated orally with EEHa $(100 \mathrm{mg} / \mathrm{Kg})$; S- satellite group. ${ }^{*} p<0.05$ versus control group.

from $H$. articulatus showed low cytotoxicity to HepG2 A16 cells in the concentrations used $\left(\mathrm{CC}_{50}>1000 \mu \mathrm{g} / \mathrm{mL}\right)$. Nevertheless, in addition to the assessment of toxicity in cell lines, it is important to evaluate the oral acute and sub-chronic toxicity of the active sample in mammals.

The group of mice acutely treated orally with a high dose of the extract $(5,000 \mathrm{mg} / \mathrm{kg})$ showed neither immediate, nor during the observation period (14 days) clinical changes. No deaths occurred in the period of the experiment and no anatomopathological changes were observed in the organs evaluated. Besides, the differences between the sexes did not influence toxicity results.

Another study evaluated the acute toxicity of the extract from leaves of $H$. drasticus, with the animals showing signs of excitability, agitation and increased respiratory rate $($ dose $=2,000 \mathrm{mg} / \mathrm{kg}$ ) [50]. Nevertheless, neither histopathological changes, nor other signs of toxicity were observed, suggesting that species of the genus Himatanthus have low acute toxicity.

No clinical changes or in water/chow intake were observed in the groups treated with the ethanol extract of $H$. articulatus. However, significant changes were observed on haematological and biochemical parameters (Tables 4 and 5).

In the present study, haematological alterations were observed only in females, even in the group treated with the lowest dose (Table 4). At a dose of $100 \mathrm{mg} / \mathrm{kg}$ in females, the following changes were observed: increases in red blood cell-count, haemoglobin, haematocrit, $\mathrm{MCV}$ and $\mathrm{MCHC}$ (Table 4). The elevations of MCV and MCHC suggest macrocytosis and this should be investigated. In addition, there was an increase in the number of platelets and leukocytes. However, at the highest dose, these changes were only observed in the satellite group (Table 4).

It is known that females are more vulnerable to adverse drug reactions, as well as its toxic effects. Perhaps, the hormones related to this gender change significantly the pharmacokinetic aspects. These changes, perhaps, might have contributed to the vulnerability to toxic hematological effects. The biochemical changes occurred in both genders, being that in males it was seen at the highest dose (200 $\mathrm{mg} / \mathrm{kg}$ ). The reduction of albumin and total protein may be related to the inhibition of hepatic protein synthesis. Nevertheless, this inhibition is possibly reversible, as it has not been observed in the satellite group (Table 5).

Other changes observed in males included: increase of triglycerides and a reduction in uric acid levels (Table 5). The increase of uric acid synthesis has been related to increased antioxidant activity. It is also a marker of the ischemia-reperfusion syndrome [51]. In the present study, the decrease of uric acid may suggest a lesser extent of ischemic events than in the control group. In the group of male animals, treated with 200 and $100 \mathrm{mg} / \mathrm{kg}$ of extract, a significant reduction of hepatic TBARS was observed. On the other hand, in the group of females TBARS levels were significantly increased (Figure 4). TBARS is a widely used lipid peroxidation marker and its increase can

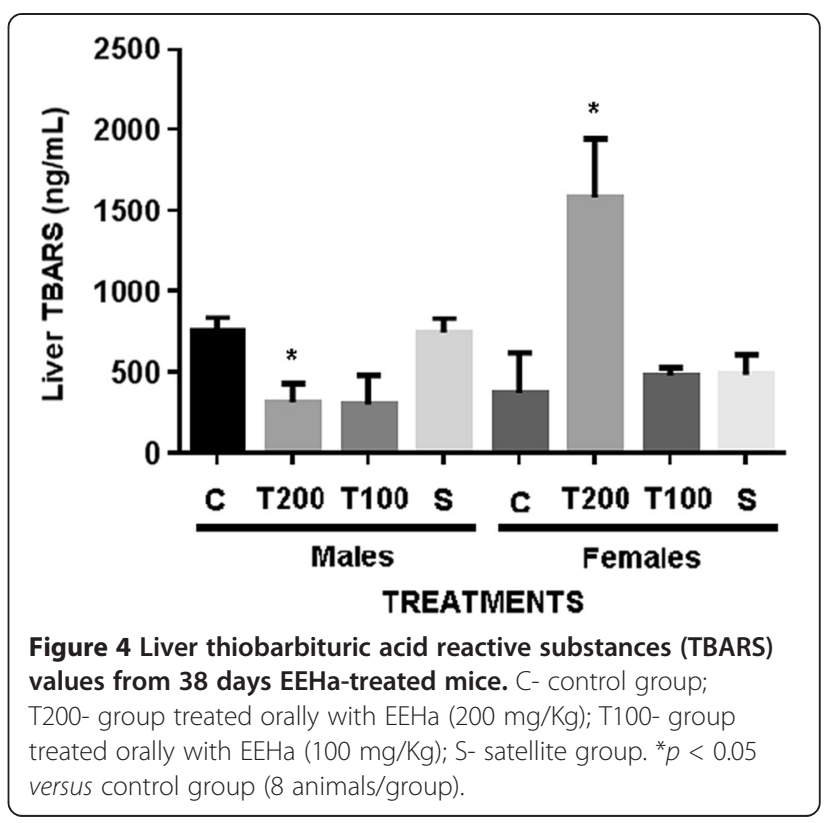


suggest high rate of cell membrane damage, while the reduction in male can signal the reduction of damage. As stated earlier, changes in pharmacokinetic properties, and in particular in the metabolism, might justify the differences in the responses amongst genders.

\section{Conclusion}

An extract from $H$. articulatus bark containing plumieride as the major constituent. The ethanol extract from $H$. articulatus stem barks, although inactive in vitro (against $P$. falciparum), showed activity against $P$. berghei in an in vivo study. The ethanol extract may contain a substance that after metabolism becomes active. Another relevant fact found in the present study was the safety of this extract. The ethanol extract showed low cytotoxicity $\left(\mathrm{IC}_{50}>1000\right.$ $\mathrm{mg} / \mathrm{mL}$ ), causing no significant clinical changes both in acute and sub-chronical administration. Besides, no histopathological changes were observed. Only biochemical and haematological reversible changes were observed. This study attested some anti-malarial activity of the $H$. articulatus extracts, as well as its safety, thus validating its popular use.

\section{Competing interests}

The authors declare that they have no competing interests.

\section{Authors' contributions}

W: preparation of the ethanol and dichloromethane extracts, extraction, fractionation and isolation of the compounds, spectroscopic studies, writing and editing of the manuscript; TCV: in vivo anti-malarial test, acute oral and sub-chronic toxicity studies; RCST and MRCF: collection and botanical identification of plant material; SP: oxidative stress studies, hematological and biochemical parameters interpretation results and review of the manuscript; LFS: conduction the study of anti-plasmodial activity in vitro and cytotoxicity assay; WLAP: performed the histopathological studies; GCB: Interpretation of the spectroscopic data; ABO: extraction, fractionation and isolation of the compounds, spectroscopic studies and review of the manuscript; MFD: in vivo anti-malarial activity, writing and reviewing of the manuscript; FV: acute oral and sub-chronic toxicity tests design and results rendering, hematological and biochemical parameters interpretation, drafting and writing of the final manuscript. All of the authors have read and approved the final manuscript.

\section{Acknowledgements}

The authors gratefully acknowledge the financial support from National Counsel of Technological and Scientific Development (Conselho Nacional de Desenvolvimento Científico e Tecnológico - CNPq), PRONEX-CNPq, Fundação de Amparo à Pesquisa do Estado de Minas Gerais (FAPEMIG), Fundação Amazônia Paraense de Amparo à Pesquisa (FAPESPA), PPSUS-FAPESPA.

\footnotetext{
Author details

${ }^{1}$ Programa de Pós-graduação em Ciências Farmacêuticas, Instituto de Ciências da Saúde (ICS), Universidade Federal do Pará (UFPA), Rua Augusto Corrêa 1, 68075-110 Belém, PA, Brazil. ²Departamento de Botânica, Museu Paraense Emilio Goeldi, Belém, PA, Brazil. 'Laboratório de Pesquisa em Estresse Oxidativo, Instituto de Ciências Biológicas (ICB), Universidade Federal do Pará (UFPA), Belém, PA, Brazil. ${ }^{4}$ Faculdade de Farmácia, Universidade Federal de Minas Gerais, Belo Horizonte, MG, Brazil. ${ }^{5}$ Departamento de Patologia Veterinária e Medicina Preventiva, Instituto de Saúde e Produção Animal (ISPA), Universidade Federal Rural da Amazônia, Belém, PA, Brazil. ${ }^{6}$ Programa de Pós-graduação em Inovação Farmacêutica, Instituto de Ciências da Saúde (ICS), Universidade Federal do Pará (UFPA), Belém, PA, Brazil. ${ }^{7}$ US Centers for Disease Control and Prevention (CDC), Atlanta, GA, USA. ${ }^{8}$ Escola de Farmácia, Universidade Federal de Ouro Preto, Ouro Preto, MG, Brazil.
}

Received: 14 October 2014 Accepted: 7 March 2015

Published online: 27 March 2015

\section{References}

1. 1-WHO: World Malaria Report. Geneva, World Health Organization, 2013 [http://www.who.int/malaria/publications/world_malaria_report_2013/en/]

2. Oliveira-Ferreira J, Lacerda MVG, Brasil P, Ladislau JLB, Tauil PL, Daniel-Ribeiro CT. Malaria in Brazil: an overview. Malar J. 2010;9:115.

3. Brasil, Secretaria de Vigilância em Saúde - Ministério da Saúde. Situação epidemiológica da malária no Brasil 2000 a 2011. Bol Epidemiol. 2013;44:1-16.

4. Meshnick SR, Dobson MJ. The history of anti-malarial drugs. In: Rosenthal PJ, editor. Anti-malarial Chemotherapy. Totow: Humana Press; 2001. p. 15-25.

5. White NJ. Anti-malarial drug resistance. J Clin Invest. 2004;113:1084-92.

6. Wongsrichanalai C, Pickard AL, Wernsdorfer WH, Meshnick SR. Epidemiology of drug-resistant malaria. Lancet Infect Dis. 2002;2:209-18.

7. Oliveira AB, Dolabela MF, Braga FC, Jacome RLRP, Povoa MM. Plant-derived anti-malarial agents: new leads and efficient phythomedicines. Part I Alkaloid An Acad Bras Cienc. 2009;81:715-40.

8. Dolabela MF, Oliveira SG, Nascimento JMS, Peres JMV, Wagner H, Povoa MM, et al. In vitro anti-plasmodial activity of extract and constituents from E. febrifuga, a plant traditionally used to treat malaria Brazilian amazon. Phytomedicine. 2008:15:367-72.

9. Di Stasi LC, Hiruma-Lima CA. Gentianales medicinais. In: Di Stasi LC, HirumaLima CA (orgs.), editor. Plantas medicinais na Amazônia e na Mata Atlântica. São Paulo, Brazil: Editora da UNESP; 2002. p. 375-85.

10. Van Den Berg ME. Plantas medicinais na Amazônia: contribuição ao seu conhecimento sistemático. Belém, Brazil: CNPq/PRU/MPEG; 1982.

11. Gilbert B. Produtos naturais industrializáveis da Amazônia. Fitos. 2006;2:30-8.

12. Miranda ALP, Silva JRA, Rezende CM, Neves JS, Parrini SC, Pinheiro MLB, et al. Anti-inflammatory and analgesic activities of the látex containing triterpenes from Himatanthus sucuuba. Planta Med. 2000;66:284-6.

13. Elizabetsky E, Castilhos C. Plants used as analgesics by Amazonian caboclos as a basis for selecting plants for investigation. Int J Crude Drug Res. 1990;28:309-20.

14. Milliken W. Traditional anti-malarial medicine in Roraima- Brazil. Econ bot. 1997;51:212-37.

15. Kvist LP, Christensen SB, Rasmussen HB, Mejia K, Gonzalez A. Identification and evaluation of Peruvian plants used to treat malaria and leishmaniosis. J Ethnopharmacol. 2006;106:390-402.

16. Spina AP, Bittrich V. Kinoshita: Typifications, new synonyms and a new combination in Himatanthus (Apocynaceae). Taxon. 2013;62:1304-7.

17. Woodson RE. Studies in the Apocynaceae. VII - An evaluationof the genera Plumeria L. and Himatanthus Willd. Ann Mo Bot Gard. 1938;25:189-24.

18. Lorenzi H, Matos FJA. Himatanthus sucuuba (Sprice) Wood. In: Lorenzi H, Matos FJA, editors. Plantas medicinais no Brasil: nativas e exóticas cultivadas. São Paulo, Brazil: Instituto Plantarum; 2002. p. 68-9.

19. Silva JRA, Rezende CM, Pinto AC, Pinheiro MLB, Cordeiro MC, Tamborini E, et al. Ésteres Triterpênicos de Himatanthus Sucuuba (Spruce) Woodson. Quim Nova. 1998;21:702-4.

20. Silva JRA, Amaral ACF, Silveira CV, Rezende CM, Pinto AC. Quantitative determination by HPLC of iridoids in the bark and latex of Himatanthus sucuuba. Acta Amazon. 2007;37:119-22.

21. Goulart HB, Kimura EA, Peres VJ, Couto AS, Duarte FAA, Katzin AM. Terpenes arrest parasite development and inhibit biosynthesis of isoprenoids in Plasmodium falciparum. Antimicrob Agents Chemother. 2004;48:2502-9.

22. Amoa-Onguené $P$, Ntie-Rang F, Lifongo LL, Ndom JC, Sippl W, Mbaze LM. The potential of anti-malarial compounds derived from African medicinal plants. Part I: A pharmacological evaluation of alkaloids and terpenoids. Malar J. 2013;12:449.

23. Rattmann YD, Terluk MR, Souza WM, Santos CAM, Biavatti MW, Torres LB, et al. Effects of alkaloids of Himatanthus lancifolius (Muell. Arg.) Woodson, Apocynaceae, on smooth muscle responsiveness. J Ethnopharmacol. 2005;100:268-75

24. Yubin Jl, Miao Y, Bing W, Yao Z. The extraction, separation and purification of alkaloids in the natural medicine. J Chem Pharm Res. 2014;6:338-45.

25. Mosman T. Rapid colorimetry assay for cellular growth and survival: application to proliferation and cytotoxicity assay. J Immunol Methods. 1983;65:55-63.

26. Trager W, Jensen JB. Human malaria parasites in continuous culture. Science. 1976;193:673-5.

27. Lambros C, Vanderberg JP. Synchronization of Plasmodium falciparum erythrocytic stages in culture. J Parasitol. 1979;65:418-20. 
28. Makler MT, Ries JM, Williams JA, Bancroft JE, Piper RC, Gibbins BL, et al. Parasite lactate dehydrogenase as an assay for Plasmodium falciparum drug sensitivity. Am J Trop Med Hyg. 1993;48:739-41.

29. Nkhoma S, Molyneux M, Ward S. In vitro anti-malarial susceptibility profile and prcrt/pfmdr-1 genotypes of Plasmodium falciparum field isolates from Malasi. Am J Trop Med Hyg. 2007;76:1107-12.

30. Organization for Economic Cooperation and Development. OECD. Guideline for Testing of Chemicals. Guideline 420: Acute oral Toxicity-Acute Class Method. Paris, France: OECD Publishing; 2001.

31. Organization for Economic Cooperation and Development. OECD. Guideline for Testing of Chemicals. Guideline 407. Repeated dose 28-day oral toxicity study in rodents. Paris, France: OECD Publishing; 1995.

32. Peters W. Drug resistance in Plasmodium berghei. I Chloroquine resistance Exp Parasitol. 1965;17:80-9.

33. Miller N, Rice-Evans C, Davies M, Gopinathan V, Milner A. A novel method for measuring antioxidant capacity and its application to monitoring the antioxidant status in premature neonates. Clin Sci. 1993;84:407-12.

34. Percario S, Vital ACC, Jablonka F. Dosagem de malondialdeído. Newslab. 1994:2:46-50.

35. Green JS, Wagner DA, Glogowski J, Skipper PL, Wishnok JS, Tannenbaum SR. Analysis of nitrate nitrite and $\left({ }^{15} \mathrm{~N}\right)$ nitrate in biological fluids. Anal Biochem. 1982;126:131-8.

36. Barreto AS, Amaral ACF, Silva JRA, Schripsema J, Rezende CM, Pinto AC. Acido 15-desmetilisoplumierídeo, um novo iridóide isolado das cascas de Plumeria rubra e do látex de Himatanthus sucuuba. Quim Nova. 2007:30:1133-5.

37. Plouvier V, Favre-Bonvin J. Les iridoids et seco-iridoids: repartition, structure, propietes, biosyntese. Phytochemistry. 1971;10:1697-722.

38. Pereira MM, Jácome RLRP, Alcantara AFC, Alves RB, Raslan DS. Alcalóides indólicos isolados de espécies do gênero Aspidosperma (Apocynaceae). Quim Nova. 2007;30:970-83.

39. Rebouças SO, Grivicich J, Santos MS, Rodriguez P, Gomes MD, Oliveira SQ, et al. Antiproliferative effect of a traditional remedy Himatanthus articulatus bark on human cancer cell lines. J Ethnopharmacol. 2011;137:926-9.

40. Cazarin KCC, Corrêa CL, Zambrone FAD. Redução, refinamento e substituição do uso de animais em estudos toxicológicos: uma abordagem atual. Braz J Pharm Sci. 2004;40:290-9.

41. Kuria KAM, Chepkwony H, Govaerts C, Roets E, Busson R, Witte P, et al. The anti-plasmodial activity of isolates from Ajuga remota. J Nat Prod. 2002;65:789-93.

42. Carvalho LH, Brandão MGL, Santos-Filho D, Lopes JLC, Krettli AU. Anti-malarial activity of crude extracts from brazilian plants studied in vivo in Plasmodium berghei infected mice and in vitro against Plasmodium falciparum in culture. Braz J Med Biol Res. 1991;24:1113-23.

43. Mahajan S, Atkins WM. The chemistry and biology of inhibitors and pro-drugs targeted to glutathione S-transferases. Cell Mol Life Sci. 2005;65:1221-33.

44. Gillrie MR, Krishnegowda G, Lee K, Buret A, Robbins SMS, Looareesuwan S, et al. Src-family kinase-dependent disruption of endothelial barrier function by Plasmodium falciparum merozoite proteins. Blood. 2007;110:3426-35.

45. Adhikari KNJ, Burns KEA, Friedrich JO, Granton JT, Cook DJ, Meade MO. Effect of nitric oxide on oxygenation and mortality in acute lung injury: systemactic review and meta-analysis. BMJ. 2007;334:1-8.

46. Pino P, Taoufiq Z, Nicheu J, Vouldoukis I, Mazier D. Blood-brain barrier breakdown during cerebral malaria: suicide or murder? J Thromb Haemost. 2005;94:336-40.

47. Dimmeler S, Haendeler J, Nehls M. Zeiher: Suppression of apoptosis by nitric oxide via inhibition of interleukin-1 $\beta$-converting enzyme (ICE)-like and cysteine protease protein (CPP)-32-like proteases. J Exp Med. 1997;185:601-8.

48. Jeong EJ, Lee KY, Kim SH, Sung SH, Kim YC. Cognitive-enhancing and antioxidant activities of iridoid glycosides from Scrophularia buergeriana in scopolamine-treated mice. Eur J Pharmacol. 2008;588:78-84.

49. Aremu AO, Amoo SO, Ndhlala AR, Finnie JF, Van Staden J. Antioxidant activity, acetylcholinesterase inhibition, iridoid content and mutagenic evaluation of Leucosidea sericea. Food Chem Toxicol. 2011;49:1122-8.

50. Souza EL, Grangeiro ARS, Bastos IVGA, Rodrigues GCR, Silva MJ, Anjos FBR, et al. Antitumor activity of leaves of Himatanthus drasticus (Mart.) Plumel Apocynaceae (Janaguba) in the treatment of Sarcoma 180 tumor. Braz J Pharm Sci. 2010:46:199-203.

51. Halliwell B, Gutteridge JMC. Free Radicals in Biology and Medicine. 4th ed. USA: Oxford University Press; 2007. p. 851.

\section{Submit your next manuscript to BioMed Central and take full advantage of:}

- Convenient online submission

- Thorough peer review

- No space constraints or color figure charges

- Immediate publication on acceptance

- Inclusion in PubMed, CAS, Scopus and Google Scholar

- Research which is freely available for redistribution

Submit your manuscript at www.biomedcentral.com/submit 